\title{
Technical and Financial Analysis of Photovoltaic Water Pumping System for GORGAN, IRAN
}

\author{
${ }^{1}$ Alireza Rezae $\quad{ }^{2 *}$ S.Asghar Gholamian \\ ${ }^{1}$ Babol University of Technology, Faculty of Electrical and Computer Engineering, \\ Babol, Iran \\ a.rezaielstu.nit.ac.ir \\ ${ }^{2}$ Babol University of Technology, Faculty of Electrical and Computer Engineering, \\ Babol, Iran \\ gholamianenit.ac.ir \\ *Corresponding Author: S. Asghar Gholamian
}

\begin{abstract}
Because of human need for energy, extra special attention is in the usage of renewable-energy sources in recent years. On the other hand, environmental pollution is created with fossil energy. Photovoltaic (PV) energy is also one of the renewable-energy sources that are available in almost all parts of the globe, especially in Iran. One application of this energy is in water pumping system. In this paper, we precede the technical and financial study on photovoltaic water pumping system for irrigation of GORGAN's farm fields (one of Northern Province of Iran) with the RETScreen software tools. In order to the results, it is obvious that the usage of this clean energy causes the reduction on production costs during of its operation.
\end{abstract}

\section{KEYWORDS}

Irrigation, photovoltaic system, RETScreen software, water pumping.

\section{INTRODUCTION}

Demand of energy is more sensible now because of population growth and economic growth of countries. In order to increase of energy consumption around the world and environment pollution, attention to the renewable energy such as solar energy is inevitable.

Developed countries increase their investment in solar power plants, and IEA (International Energy Agency) projections for 2030 give an enhancement of solar electricity generation up to $13.6 \mathrm{GW}[9]$.

Iran is one of the petroleum countries and has the huge source of natural gas. Fortunately, this country has a high potential of solar projects in order to its proper solar radiation and because of this has a good economy in its fossil fuel. One of the important solar-energy conversion systems is the photovoltaic system. In these systems, solar energy is converted to electricity by solar cells [15].

Photovoltaic is a phenomenon that solar radiation energy is converted to electrical energy without mechanical mechanism. Each system operates such that is known as photovoltaic system. The Photovoltaic systems have different and varied applications in industry, domestic and even in 
research projects. In this paper, we study application of this form of energy within the agriculture system. Annually, there is a lot of cost for irrigation of agriculture land because of growth energy cost during these years.

So use of the photovoltaic system in water pumping seems commodious. Irrigation of agriculture land is in warm season, and solar radiation is in good condition so, the average time of sunny hours is admissible.

In this paper, the photovoltaic and water pumping system are introduced at first. Finally, technically and financially analyze of this system are presented in GORGAN agriculture land area using RETScreen software tools. Location of GORGAN is shown in figure (1) in Iran's map.

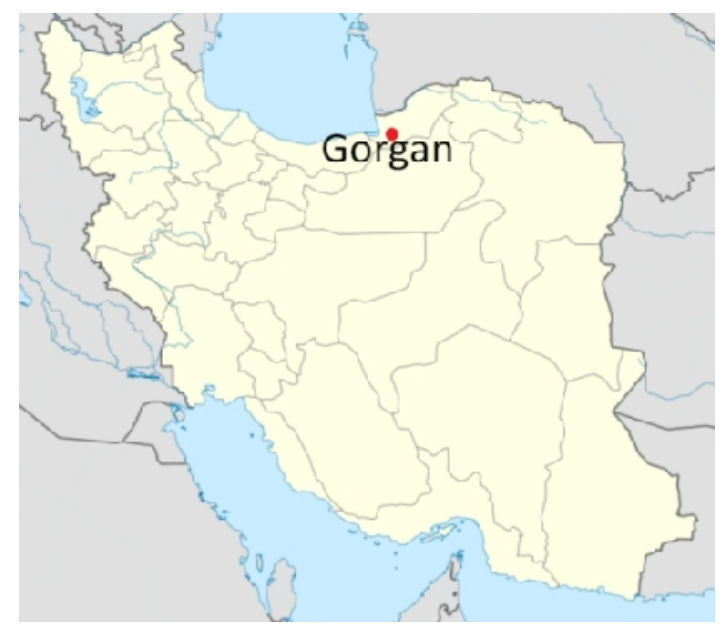

Figure1. Location of GORGAN in Iran's map [25]

Financial and technical analysis of photovoltaic water pumping system in GORGAN farm fields for the first time is the novelty of this paper.

\section{Photovoltaic System}

The photovoltaic system consists of three main parts [18]:

a) Photovoltaic module or panel that converts solar energy to electrical energy.

b) Power part that manages electrical energy in order to user demand.

c) Consumption or electrical load that consists of whole demand as DC or AC demand.

Stand-alone and grid-connected are two main photovoltaic system. As its name implies, the standalone (off-grid) PV system operates independently of any other power supply, and it usually supplies electricity to private load or loads. It includes a storage facility (e.g. Battery bank) to allow electricity to be provided during the night or at times of poor sunshine levels.

Off-grid systems are also often operating as autonomous systems because their operation is independent of other power sources. But the grid-connected (on-grid) PV system operates in parallel with the conventional electricity distribution system or to power loads, which can also be fed from the grid. The schematic diagrams of these systems are shown in figure (2) [10]. 
International Journal on Cybernetics \& Informatics ( IJCI) Vol.2, No.2, April2013

It is conceivable to add one or more alternative power supplies such as a diesel generator to the system to provide some of the load requirements.

\section{Electrical Model of Photovoltaic and Water Pumping System}

To acquire the model of the photovoltaic cell, at first we must find the electrical equivalent circuit of that source.

Many mathematical models have been studied to represent their highly nonlinear behaviour that resulting from the semiconductor junctions.

There are several models of different photovoltaic cells as the number of parameters involved in the calculation of voltage and current of photovoltaic cell [1].

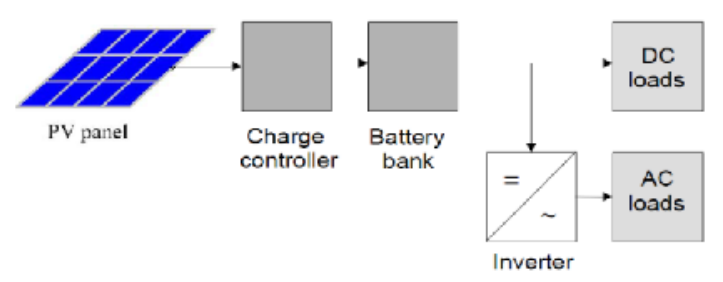

a) Off-grid system

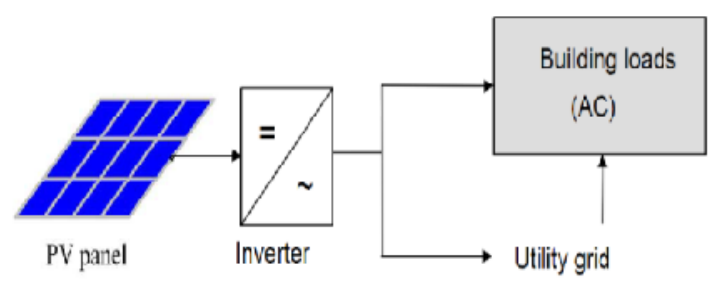

b) On grid system

Figure2. Schematic diagrams of on-grid and off-grid photovoltaic system

In this paper, we consider the model with two diodes; in fact, this model provided the different internal resistance to the PV cell (Figure3) [11].

It consists of a current source $\left(\mathrm{i}_{\mathrm{ph}}\right)$ that models the sunlight energy conversion to electrical energy; the diodes $\left(\mathrm{D}_{1}, \mathrm{D}_{2}\right)$ model the $\mathrm{PN}$ junction, a series resistance $\left(\mathrm{R}_{\mathrm{s}}\right)$ modelling the various resistance contact and connection and shunt resistance $\left(\mathrm{R}_{\mathrm{sh}}\right)$ is the result of leaks by the side effect on the photovoltaic cell [12]. 


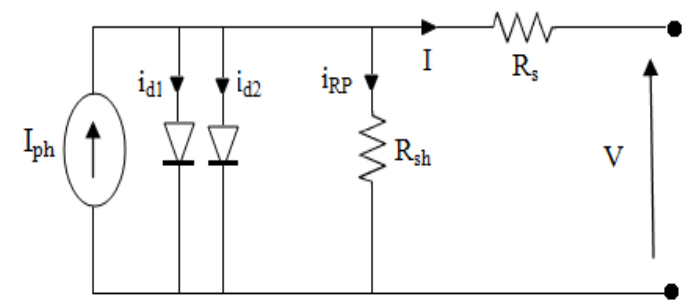

Figure3. Model of a photovoltaic cell with two diodes

$\mathrm{I}=\mathrm{I}_{\mathrm{ph}}-\mathrm{I}_{\mathrm{d} 1}-\mathrm{I}_{\mathrm{d} 2}-\mathrm{I}_{\mathrm{RP}}$

$I=I_{p h}-I_{s i} \times\left(\exp \frac{q \cdot\left(V+R_{s} \cdot I\right)}{A_{1} \cdot K \cdot T}-1\right)-I_{s 2} \times\left(\exp \frac{q \cdot\left(V+R_{s} \cdot I\right)}{A_{2} \cdot K \cdot T}-1\right)-\frac{V+R_{s} \cdot I}{R_{s h}}$

The output voltage and current of the PV express by V and I; implies the electronic charge; $\mathrm{I}_{\mathrm{ph}}$ corresponds to the light-generated current of PV panel; $\mathrm{I}_{\mathrm{S} 1,2}$ express the current saturation of two diodes; $\mathrm{A}_{1,2}$ is ideality factor of junction of diodes , $\mathrm{T}$ the cell temperature and the Boltzmann's constant[1].

From equations 1 and 2, it is obvious that the output current of the PV panel depends upon the photocurrent itself. The photocurrent depends on the solar insulation and the junction temperature of the photovoltaic cells, so the power which a module can deliver to the load depends on the solar insulation and the temperature of the junction $[2,12]$.

\subsection{Characteristics of PV Module}

Irradiation and the operating temperature of photovoltaic cell affected the output characteristic of a PV cell [3]. As shown the PV output characteristics of a PV module in Figure4 [4, 13], at a constant temperature, if the irradiation is increased, then the output power is increased too.

On the other hand, at constant irradiation conditions, if the temperature is declined, then the output power is augmented. To obtain highest power from the PV module the output voltage of a PV module should be controlled in a proper level as seen in Figure4. This is known as maximum power point tracking (MPPT) [5]-[7], [14].

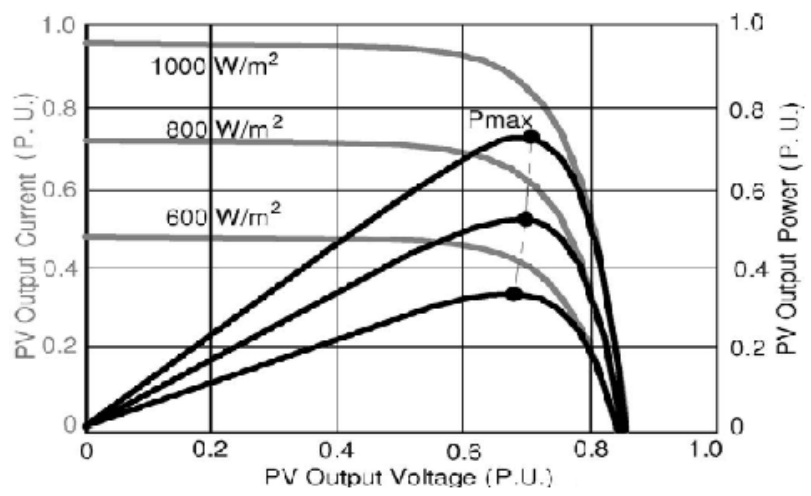

Figure4. Characteristics of a photovoltaic module [8] 


\subsection{Photovoltaic Water Pumping System}

The water pumping model that is shown in Figure5consist of PV array, power conditioner and pump [16]. The daily hydraulic energy demand $E_{\text {hydr }}$, in $J$ is relevant to lifting water to height $h$ (in $\mathrm{m}$ ) with a daily volume $\mathrm{Q}$ (in $\mathrm{m}^{3} / \mathrm{d}$ ):

$E_{\text {hydr }}=86400 \rho g Q h\left(1+\eta_{f}\right)$

Where $\mathrm{g}$ is the acceleration of gravity $\left(9.81 \mathrm{~ms}^{-2}\right)$, the density of water $\left(1000 \mathrm{~kg} / \mathrm{m}^{-3}\right)$, and $\eta_{\mathrm{f}}$ is a coefficient of friction losses in the piping. This hydraulic energy converts to an electrical energy requirement $\mathrm{E}_{\text {pump }}$ :

$E_{\text {pump }}=\frac{E_{\text {hydr }}}{\eta_{\text {pump }}}$

Where, ,pump $_{\text {is }}$ the pump system efficiency. If the pump is $\mathrm{AC}$, this equation has to be modified by the inverter efficiency factor $\left(\eta_{\text {inv }}\right)$ :

$E_{\text {pump }}=\frac{E_{\text {hydr }}}{\eta_{\text {pump }} \times \eta_{\text {inv }}}$

Energy delivered is:

$E_{\text {dlvd }}=\eta_{\text {pump }} \min \left(E_{\text {pump }}, E_{A}\right)$

Where $\mathrm{E}_{\mathrm{A}}$ is the energy available from the photovoltaic array (this quantity should be multiplied by $\eta_{\text {inv }}$ if the pump is $\left.\mathrm{AC}\right)$, and daily water delivered $\left(\mathrm{Q}_{\mathrm{dlvd}}\right)$ is:

$\mathrm{Q}_{\mathrm{dlvd}}=\frac{\mathrm{E}_{\mathrm{dlvd}}}{86400 \mathrm{\rho gQh}\left(1+\eta_{\mathrm{f}}\right)}$

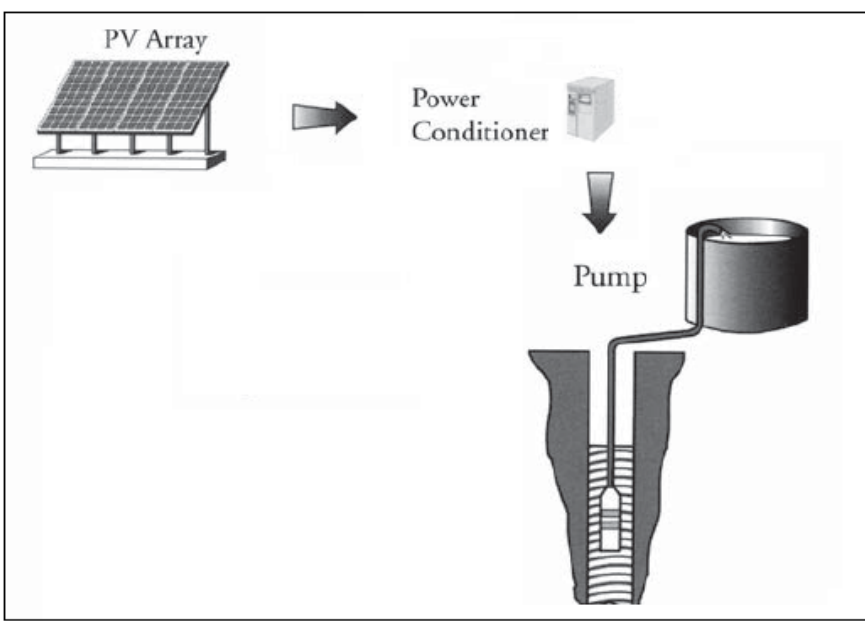

Figure.5 Water pumping PV system schematic 


\section{Photovoltaic Water Pumping Design}

To design a photovoltaic system for irrigation of agriculture land after allocating the daily electricity, we can use the algorithm as seen in Figure6. To irrigate each hectare it requires a 1.5 KW single phase motor that should be operated 10 hours a day. The irrigation time is from April to September.

We choose a 220 volts single phase $1.5 \mathrm{KW}$ ac motor with 0.9 lagging power factor for this system. As mentioned this motor should be operated 10 hours per day so, daily watt hour is 15000 WH per day. By considering 48v for storage system voltage, the daily ampere hour is $312.5 \mathrm{AH}$ per day.

Fortunately, in the rainy atmosphere there is no need to irrigate so; final cost of energy is decreased. The most days that system can operate autonomously is considered one day. The sunny hours in a day is considered as six hours [17] so, the charge current control is 65 ampere. In order to maximum power of each panel and charge current control the number of photovoltaic panel is fourteen with $195 \mathrm{~W}$ nominal powers. The loss coefficient of the battery and state of charge of the battery respectively is considered as 1.2 and 0.8 so, total ampere hour of the battery bank is $470 \mathrm{AH}$. If we use a battery with $100 \mathrm{AH}$ then have a five parallel branch in battery bank.

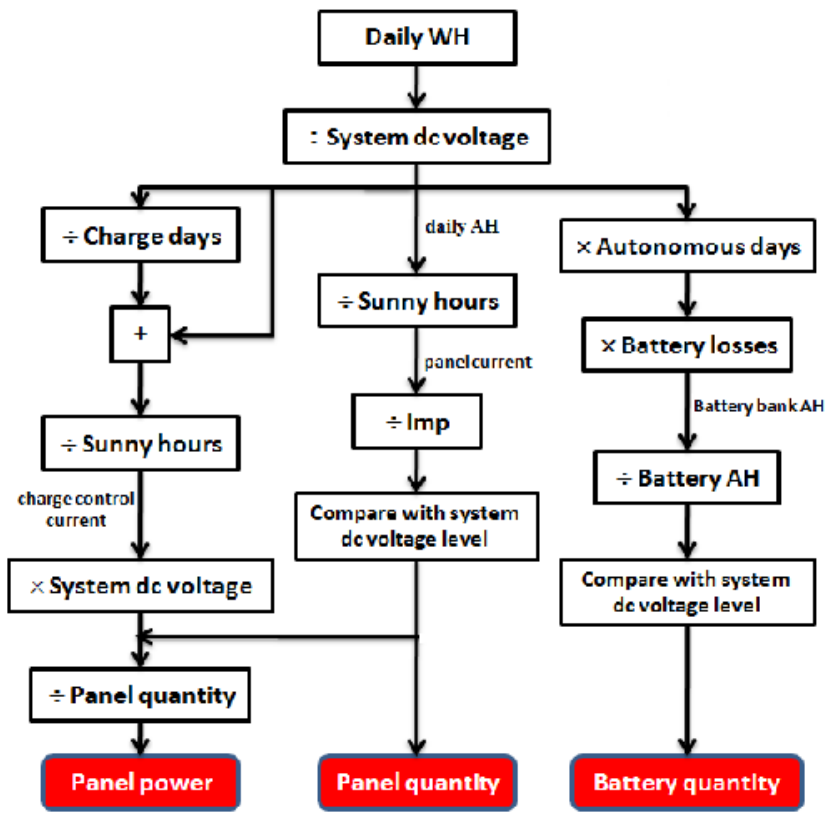

Figure6. Photovoltaic system design algorithm

There are four batteries in each branch because; the battery voltage level is $12 \mathrm{v}$ whereas the battery bank voltage level is $48 \mathrm{v}$. Therefore twenty $100 \mathrm{AH}$ battery can construct the battery bank. And finally the project operation cost is as table 1. There are Characteristics and technical information of system configuration in appendix. 
International Journal on Cybernetics \& Informatics ( IJCI) Vol.2, No.2, April2013

Table1. Project implementation cost in dollars

\begin{tabular}{|c|c|c|c|}
\hline $\begin{array}{c}\text { Total } \\
\text { cost }\end{array}$ & Cost & Number & Product \\
\hline 4950 & 330 & 15 & PV panel \\
\hline 754 & 754 & 1 & $\begin{array}{c}\text { Charge } \\
\text { control }\end{array}$ \\
\hline 1600 & 80 & 20 & Battery \\
\hline 557 & 557 & 1 & Inverter \\
\hline
\end{tabular}

\section{Project Analysis with Software}

RETScreen is an Excel-based clean and renewable energy project analysis software tool that helps decision makers rapidly and inexpensively determines the technical and financial viability of potential renewable energy, energy efficiency and cogeneration projects [23].

To survey this project with RETScreen software tool financially, the area information and characteristics of system configuration such as water pumping system, photovoltaic panel and battery and so on should be defined. Pumping head nomenclature and Water pumping load characteristic are respectively shown in Figure7 and table (3).

The area of this project is in GORGAN in northern Iran with latitude $36.8{ }^{\circ} \mathrm{N}$ and longitude 54.5 ${ }^{\circ} \mathrm{E}$. Solar radiation in months of year in $\mathrm{KWH} / \mathrm{m}^{2} / \mathrm{d}$ is shown in table (2). This information is obtained from weather base of RETScreen software.

Table2. GORGAN solar radiation

\begin{tabular}{|c|c|}
\hline Month & Solar radiation \\
\hline January & 2.53 \\
\hline February & 3.27 \\
\hline March & 4.07 \\
\hline April & 5 \\
\hline May & 5.79 \\
\hline June & 6.42 \\
\hline July & 6.10 \\
\hline August & 5.68 \\
\hline September & 4.75 \\
\hline October & 3.70 \\
\hline November & 2.69 \\
\hline December & 2.20 \\
\hline Average & 4.35 \\
\hline
\end{tabular}


International Journal on Cybernetics \& Informatics ( IJCI) Vol.2, No.2, April2013

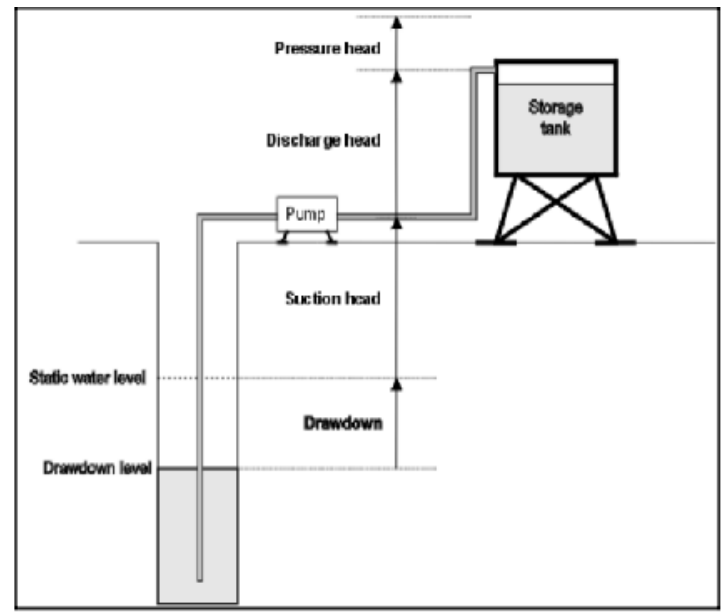

Figure7. Pumping head nomenclature

Table3. Water pumping load characteristic in RETScreen

\begin{tabular}{|c|c|c|}
\hline Daily water use & $\mathbf{M}^{3} / \mathrm{d}$ & 200 \\
\hline Suction head & $\mathrm{m}$ & 7 \\
\hline drawdown & $\mathrm{m}$ & 5 \\
\hline Discharge head & $\mathrm{m}$ & 1 \\
\hline Pressure head & $\mathrm{m}$ & 1 \\
\hline Friction losses & $\%$ & 15 \\
\hline Daily mechanical energy & $\mathrm{kWh}$ & 8.77 \\
\hline Pump \& motor efficiency & $\%$ & $77^{*} .80$ \\
\hline Daily electricity & $\mathrm{kWh}$ & 14.38 \\
\hline
\end{tabular}

In financial analysis of this project implementation, the income that obtained is compared with diesel system. The inflation rate and project life time are respectively considered as 10 percent and 25 years.

To irrigate the agriculture land by diesel system we need 1800 litters gas oil annually. Consider the gasoil cost is $0.125 \$$ [24] (the subsidies cost) for each litter so the annually fuel cost is $225 \$$. Instead if we use photovoltaic water pumping system then the payback of investment is 14 years as shown in cumulative cash flow in Figure8.

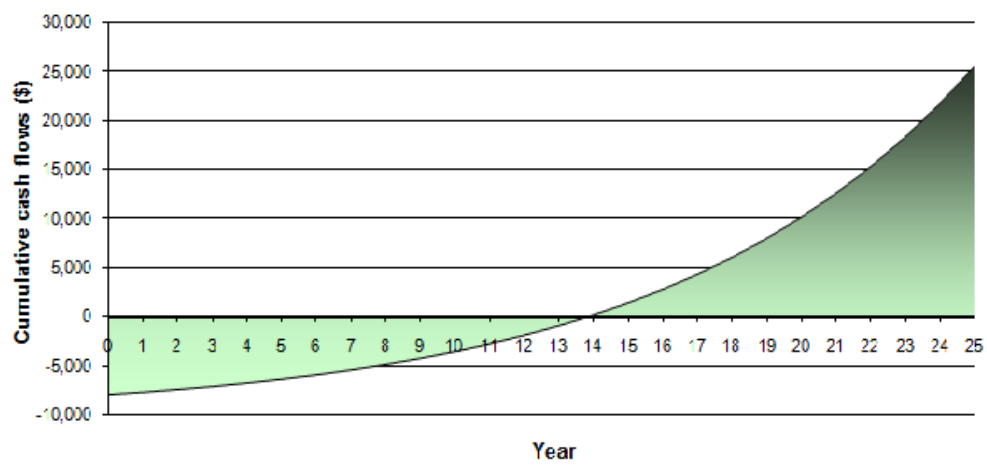

Figure8. PV water pumping cumulative cash flow in comparison with subsidies cost of gasoil 
Consider the gasoil cost is $0.5 \$$ for each litter (the product cost in the FOB Persian gulf market) then the annual fuel cost is $900 \$$ for each hectare. The cumulative cash flow is shown in Figure9. It seems that the payback in this case is 6 years and after six years the income of project implementation by photovoltaic water pumping system is considerable.

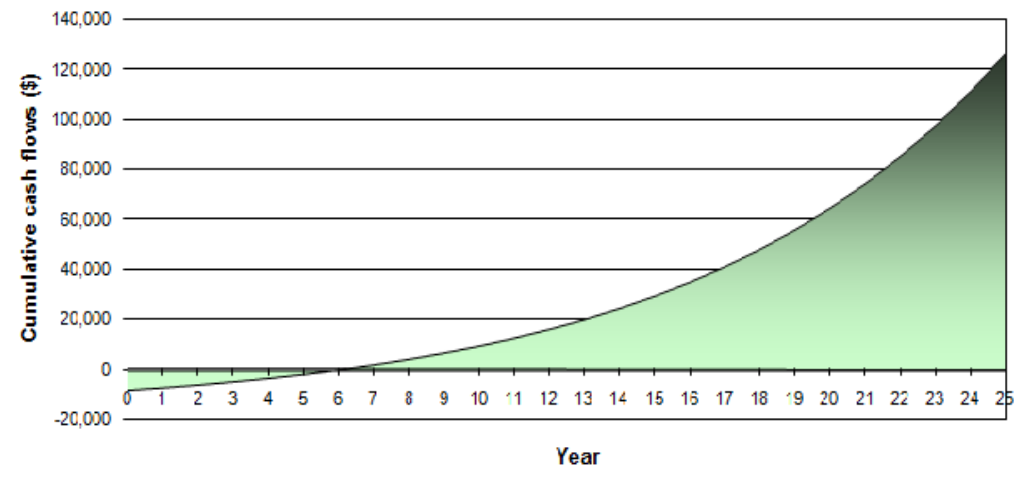

Figure9. PV water pumping cumulative cash flow in comparison with FOB Persian Gulf market cost of gasoil

\section{Conclusions}

In order to overcome the concern about the restriction of fossil-fuel source and environment pollutions, the clean and renewable-energy organizations and agencies' special attention to manage energy is essential. In this paper, financial and technical calculation is performed on photovoltaic water pumping system for irrigation in GORGAN (one of the northern province of Iran) using weather data.

The result is shown that despite the primary cost of photovoltaic water pumping project implementation, after investment payback, there is a considerable saving in costs. Government can improve and expand the use of this clean energy by a harmonious program and lending the long-term loan to clean energy applicants.

\section{References}

[1] F.Bouchafaa, I.Hamzaoui, A.Hadjammar, "Fuzzy Logic Control for the tracking of maximum power point of a PV system" 2010 Published by Elsevier Ltd. Selection and/or peer-review under responsibility of [name organizer].

[2] M. Azab, "A New Maximum Power Point Tracking for Photovoltaic Systems", Procedings of World Academy of Science, Engineering and Technology Volume 34 October 2008 ISSN 2070-3740.

[3] Jong-Pil Lee, Byung-Duk Min, Tae-Jin Kim, Dong-WookYoo, Ji-Yoon Yoo, “A Novel Topology for Photovoltaic DC/DC Full-Bridge Converter With Flat Efficiency Under Wide PV Module Voltage and Load Range” IEEE TRANSACTIONS ON INDUSTRIAL ELECTRONICS, VOL. 55, NO. 7, JULY 2008.

[4] K. Kobayashi, H. Matsuo, and Y. Sekine, "An excellent operating point tracker of the solar-cell power supply system,” IEEE Trans. Ind. Electron., vol. 53, no. 2, pp. 495-499, Apr. 2006.

[5] R.Leyva, C. Alonso, I. Queinnec, A. Cid-Pastor, D. Lagrange, and L. Martinez-Salamero, "MPPT of photovoltaic systems using extremumseeking-seeking control," IEEE Trans. Aerosp. Electron. Syst., vol. 42, no. 1, pp. 249-258, Jan. 2006.

[6] L. Wu, Z. Zhao, J. Liu, S. Liu, and L. Yuan, "Modified MPPT strategy applied in single-stage gridconnected photovoltaic system," in Proc. 8th ICEMS, Sep. 27-29, 2005, vol. 2, pp. 1027-1030.

[7] J.-M. Kwon, K.-H. Nam, and B.-H. Kwon, "Photovoltaic power conditioning system with line connection,” IEEE Trans. Ind. Electron., vol. 53, no. 4, pp. 1048-1054, Aug. 2006.

[8] Roger Gules, Juliano De Pellegrin Pacheco, HélioLeães Hey, JohninsonImhoff "A Maximum Power Point Tracking System With Parallel Connection for PV Stand-Alone Applications", IEEE TRANSACTIONS ON INDUSTRIAL ELECTRONICS, VOL. 55, NO. 7, JULY 2008. 
[9] IEA, “World Energy Outlook 2004”, International Energy Agency, Paris, IEA/OECD, 2004.

Nicola M. Pearsall, Robert Hill, "Photovoltaic Modules, Systems and Applications", northumria photovoltaic application center university of northumbria at newcastle, 2001.

[10] F.Belhachat, C. Larbes, L. Barazane, S. Kharzi, "Commandeneuro-floue d'un hacheur MPPT", 4éme conférenceinternationale "Computer Integrated Manufacturing", CIP'07, 03-04 Novembre 2007.

[11] Y. Pankow, "Étude de l'intégration de la production décentraliséedansunréseaubasse tension. Application aux générateursphotovoltaïques", Thèse de doctorat Centre national de recherché technologique de Lille 2005.

[12] B. D. Min, J. P. Lee, T. J. Kim, D. W. Yoo, and C. Y. Won, “A new topology for grid-connected photovoltaic system using converter with flat efficiency curve for all load range," in Proc. IEEE PESC, Jun. 17-21, 2007, pp. 1250-1254.

[13] Kolivandhadi, sajadmolana, "solar cell mppt system implementation with AVR microcontroller", PSC international conference, IRAN, 2011.

[14] F.Ferdosi, A.Sadeghi Y., S.M.Modares, "Study of Operation of On-Grid Photovoltaic System Under Unbalance Condition", PSC international conference, IRAN, 2011.

[15] Clean Energy Project Analysis Textbook, Photovoltaic Project Analysis Chapter, 2004.

[16] Mazandaran Meteorological Office

[17] Monshipoorsamira, faridkhalafi, "renewable energy organization magazine", 2009.

[18] www.wholesalesolar.com

[19] www.abyaran.com

[20] www.gogreensolar.com

[21] www.atlasbx.co.kr

[22] www.retscreen.net

[23] taavon1404.ir

[24] www.wikipedia.org

\section{APPENDIX}

Table4. MOTOGEN electromotor characteristics [20]

\begin{tabular}{|c|c|c|c|c|}
\hline Model & $\begin{array}{c}\text { Output } \\
\text { power }\end{array}$ & $\begin{array}{c}\text { Speed in } \\
\text { namely load }\end{array}$ & $\begin{array}{c}\text { Nominal } \\
\text { current }\end{array}$ & efficiency \\
\hline CR90L2A & $1.5 \mathrm{KW}$ & $2810 \mathrm{RPM}$ & $8.8 \mathrm{~A}$ & 77 \\
\hline Power factor & frequency & $\begin{array}{c}\text { Nominal } \\
\text { voltage }\end{array}$ & $\begin{array}{c}\text { Nominal } \\
\text { torque }\end{array}$ & $\begin{array}{c}\text { Start current to } \\
\text { nominal current }\end{array}$ \\
\hline 0.97 & $50 \mathrm{HZ}$ & $220 \mathrm{~V}$ & $5.1 \mathrm{NM}$ & $3.9 \mathrm{~A}$ \\
\hline
\end{tabular}

Table5. SANYO module characteristics [19]

\begin{tabular}{|c|c|}
\hline Model & $\begin{array}{c}\text { HIT } \\
\text { BA20 }\end{array}$ \\
\hline power & \multicolumn{2}{|c|}{195} \\
\hline Vmp (V) & \multicolumn{2}{|c|}{56.3} \\
\hline Imp (A) & 3.53 \\
\hline Voc (V) & 68.1 \\
\hline
\end{tabular}


International Journal on Cybernetics \& Informatics ( IJCI) Vol.2, No.2, April2013

\begin{tabular}{|c|c|}
\hline Isc (A) & 3.79 \\
\hline Dimensions (inches) & $51.9 * 34.6 * 1.8$ \\
\hline Revenue & $16.4 \%$ \\
\hline Weight $(\mathrm{kg})$ & 15 \\
\hline
\end{tabular}

Table6. ATLAS BX battery characteristics [22]

\begin{tabular}{|c|c|}
\hline Model & Atlas BX \\
\hline Voltage $(\mathrm{V})$ & 12 \\
\hline Capacity $(\mathrm{AH})$ & 100 \\
\hline Weight $(\mathrm{kg})$ & 16 \\
\hline
\end{tabular}

Table7. APOLLO SOLAR charge control characteristics [19]

\begin{tabular}{|c|c|}
\hline Model & Apollo T80 \\
\hline Voltage $(\mathrm{V})$ & $12 / 24 / 26 / 48$ \\
\hline Current $(\mathrm{A})$ & 80 \\
\hline Weight $(\mathrm{kg})$ & 22 \\
\hline
\end{tabular}

Table8. COTEK Inverter characteristics [21]

\begin{tabular}{|c|c|}
\hline Model & Cotek SK1500-248 \\
\hline Input dc voltage (V) & 48 \\
\hline Output ac voltage (V) & 220 \\
\hline Output power (W) & 1500 \\
\hline Revenue & 94 \\
\hline Weight $(\mathrm{kg})$ & 16 \\
\hline
\end{tabular}

